\title{
A Pedagogical Response to Decoloniality: Decolonial Atmospheres and Rising Subjectivity
}

\author{
Deanne Bell, PhD \\ University of East London \\ d.bell@uel.ac.uk
}

\begin{abstract}
The neoliberal academy is, at its core, an apparatus through which coloniality sustains itself. Despite the academy's self-promotion as a catalyzing institution that prepares students to become agents of social change and transformation some students and faculty experience it as a crucible of oppression. In this essay I trace the beginnings of a project I was a part of in which I worked alongside students who demanded that a psychology programme in the university be transformed into a force for decoloniality. I reflect on some of the conditions of coloniality that students actively resisted at one college and that exist elsewhere within the university. Juxtaposed against manifestations of coloniality in the university are synopses of student's experience of them. These synopses provide insight into why students have chosen to resist coloniality in the academy. I also outline a pedagogical response to coloniality that I created given students' desire for decoloniality. Finally, and with the permission of student artists, two liberation psychology student art projects are included to make visible the rise in subjectivity that becomes possible when a decolonial atmosphere is created within the university.
\end{abstract}

Keywords: coloniality, decoloniality, teaching, decolonial atmospheres, subjectivity 
Is the university prepared to recognize that the understanding of the world far exceeds the Western understanding of the world?

(Boaventura de Sousa Santos, 2012 pp. 12)

Student movements are calling for an end of this hypocrisy. They demand more rigorous knowledge for building a qualitatively better society. They want the university to become an engine of decoloniality: facilitating creative works (including the creation and recreation of subjectivities), ideas, and projects that advance the unfinished project of decoloniality.

(Nelson Maldonado-Torres, 2016, pp. 31)

The neoliberal academy is, at its core, an apparatus through which coloniality sustains itself. Despite the academy's self-promotion as a catalyzing institution that prepares students to become agents of social change and transformation, some students and faculty experience it as a crucible of oppression. In this essay I trace the beginnings of a project in which I worked alongside students who demanded that a psychology programme in the university be transformed into a force for decoloniality. I reflect on some of the conditions of coloniality that students actively resisted at one college and that exist elsewhere within the university. Juxtaposed against manifestations of coloniality in the university are synopses of student's experience of them. These synopses provide insight into why students have chosen to resist coloniality in the academy. I also outline a pedagogical response to coloniality that I created given students' desire for decoloniality. Finally, and with the permission of student artists, two liberation psychology student art projects are included to make visible shifts in subjectivity that become possible when a decolonial atmosphere is created within the university.

\section{Refusal of the Edubusiness Model}

In the fall of 2013 I joined the faculty of Antioch College, a small, historic, liberal arts undergraduate college in Ohio, United States of America to teach psychology as an assistant professor of psychology. The psychology curriculum included a blend of mainstream psychology courses (e.g. Abnormal Psychology, Developmental Psychology, Personality Theories) and others offered as critiques of the Western medical model (e.g. Critical Psychology, Ecopsychology, Somatic Psychology). Because, in the liberal arts tradition, students' programmes of study are interdisciplinary they are exposed to a range of logics and analyses designed to expand how they understand humanity. Psychology majors will, for example, take courses in anthropology, political economy and performance studies, closing knowledge gaps about the effects of culture, politics, economics and embodiment on human life left open by mainstream psychology. Liberal arts psychology students are therefore not solely reliant on the field of psychology for their developing, theoretical and critical understandings of the world.

Antioch College has an over 150 year-old commitment to social justice ideals. Enacted social justice values led the institution to be among the first colleges in the United States of America to appoint a woman to its board of trustees and faculty, offer comparable learning opportunities to men and women and educate African Americans 
(Antioch College, 2017). This legacy serves as a magnet attracting students ${ }^{1}$ some of whom recognize, experientially, that opening the doors of higher education widely, admitting greater numbers of historically marginalized people into a knowledge production system that overpowers their being, is socially unjust. These students quickly realize that academic institutions that subscribe to the edubusiness ${ }^{2}$ model lure peripheralized people unto their campuses by advertising these spaces as havens where intellectual and social nurturing may be had. In short order they describe feeling exploited by a system that seeks to exchange resources they bring (in the form of tuition income and increases in marketable diversity metrics) for debilitating student loans and the myth of well paid employment prospects post graduation. The nail in the coffin of hope arrives when these historically inferiorized Others see and feel that it is not their being that is invited into the university but the cash flows that follow their bodies' arrival on campus. It is then that they know that coloniality-the competent extension of a centuries old social, economic and cultural ethnoclass system-is not something they will only study in a course whose topic is the third world Other but an idea that accurately describes their experience. These people, using the critical thinking skills they are being taught, come to see that social transformation in the academy has stalled and that their belief that the university is an instrument for decoloniality is a fantasy.

Dismissal of Whitestream ${ }^{3}$ Psychology's Project

If coloniality is the enduring reenactment and multiply determined defeat of the inferiorized Other in the (post)colonial (Maldonado-Torres, 2016) then collective trauma -the pain and suffering produced in coloniality's wake-is the open wound, the psychical damage, the collapse of psychic life (Oliver, 2004) that flattens subjectivity, intersubjectivity and the possibility of humanity within the self. The effects of coloniality are had on both the selves of those mangled by coloniality as well as those savouring the fruits of coloniality's capitalism ${ }^{4}$. Traumatic, intersubjective, colonially produced violence against the psyche overwhelms consciousness in a way that splits the self from knowledge and understanding of itself. Coloniality, therefore, produces psychic alienation. Higher education institutions ignore these traumas through the refusal to develop curricula that could meaningfully respond to these injuries. Instead, these institutions pursue the delivery of a 'Whitestream' (Grande, 2008, p. 233) canon, a

\footnotetext{
${ }^{1}$ During the period I taught at Antioch College (from 2013-2016) the student body was comprised primarily of young people from middle and working class backgrounds. A minority of students identified as African American, Native American, Latina/o, differentially abled and sexually fluid.

${ }^{2}$ The edubusiness model of education is based on the commercialization of teaching, learning and related activities such as research.

${ }^{3}$ I use Grande's neologism "Whitestream" to highlight the conflation of 'mainstream' and 'whiteness' in the academy and broader social world.

4 'Coloniality's capitalism' is used to mark the political economic system that utilizes the tools of coloniality, namely its dehumanizing and inferiorizing strategies to exploit the oppressed.
} 
conduit through which self knowledge, self understanding and journeys towards collective healing remain elusive.

In 2014, undergraduate students at Antioch College, on a quest to reconstitute themselves and their communities outside of coloniality, began to demand a curriculum that increases their knowledge and understanding of what is theorized as coloniality and decoloniality. They specifically asked for coursework that could help them understand the psychological effects of these ways of being on people's lives. Students' needs emerged from their awareness that regardless of our social location, we-singularly and jointly, historically and psychosocially-continue to experience collective trauma as a consequence of coloniality.

In the rehearsal for decoloniality that I was part of at Antioch College students' "efforts at rehumanizing the world" (Maldonado-Torres, 2016, p. 10) resulted in a search for distinctive ideas, praxes and ways of being with the self and others. Depressed by and critical of Whitestream psychology's theories of pandemic distress students refused to accept its explanations of individual, personality and developmental abnormalities in cognition and mood. They already had first-hand knowledge of these doctrines as some of them had been diagnosed and oppressed by this mental health regime. They yearned for new ways to understand their pain based on their sense that the anguish they are experiencing is symptomatic of social pathology expressed as individual distress (Kleinman, Das and Lock, 2003).

Students also began to abandon inferiorized views of themselves constructed by Whitestream psychology's dominant research tradition. They became critical users of empiricism. The students critiqued and dismissed harmful interpretations of data mined from their communities. They came to see that the academy had further violated their right to self knowledge and self understanding through its enactment of 'epistemological violence' (Teo, 2010) -the practice of theoretically interpreting research findings to produce knowledge that results in social constructions of the Other as inferior and/or problematic.

Rather than capitulate to the university and Whitestream psychology's active onslaught against themselves, these students sought to understand our ${ }^{5}$ suffering by posing new questions. Their inquiry explored links between politics, economics, history, culture, place, spirituality and the conditions of psychic life given their experience of collective trauma. They searched for concepts that would support the development of their voice and that would enable their own articulation of the inhuman conditions produced by coloniality. They wanted to learn how to uncover their desire for an anticolonial world in which relationships are not marked by brutality or indifference but by love.

Rejection of Social Justice Education as a Substitute for Decoloniality

\footnotetext{
${ }^{5}$ One of the shifts away from coloniality toward decoloniality is the ability to experience a disalienated self in which a rigid sense of ' $I$ ' loosens and ego positions give way to a sense of we/us/our.
} 
The commercial success of the academy has become increasingly reliant on enrollment of the inferiorized Other under the auspices of terms such as "widening participation" and "increasing access". Higher education managers have supported a curricular response aware that the Other will not readily recognize themselves in the Whitestream canon. Elective courses (but not core courses in major programmes) and/or minor degree programmes (e.g. race/gender/disability studies) offer the opportunity to study (post)colonial thought on issues such as institutional and systemic power, human rights, diversity, difference and multiculturalism under the aegis of social justice education.

Social justice education has supported the development of students' analytic abilities in ways synonymous with deconstructionism. It has also promoted an analysis of oppression from an intersectional identity perspective and is a venue from which academics monitor how social injustices are normed and reproduced in higher education itself (Landerman \& MacDonald-Dennis, 2013). However, few social justice educational programmes have authored reconstructive, creative, participatory or emancipatory theories or practices (Grande, 2008) that are known to serve poor, non-white, sexually fluid, differentially abled, mature students. And, as Antioch College students who were exposed to this pedagogical approach to change observed, in some settings this approach lacks depth and fails to connect social injustice with psychic life, where its impact is cruelly felt.

As a form of Whitestream (post)colonial critical pedagogy developed in response to a succession of Western dehumanizations, social justice education promotes "change that merely furthers the dictates of market imperatives" rather than "change that emancipates" (Grande, 2008, p. 247). It is seen, therefore, as a dialogue with coloniality and not as a mobilizer of decoloniality.

\section{A Pedagogical Response to Decoloniality}

...decoloniality refers to efforts at rehumanizing the world, to breaking hierarchies of difference that dehumanize subjects and communities and that destroy nature, and to the production of counter-discourses, counter-knowledges, counter-creative acts, and counter-practices that seek to dismantle coloniality and to open up multiple other forms of being in the world.

(Nelson Maldonado-Torres, 2016, pp. 31)

Breakthroughs that open up the possibility for decoloniality are often psychological. Psychologies alert to social suffering, collective trauma and the "psychic wounds of colonialism and globalization" (Watkins and Shulman, 2008, p. 49) support the development of critical self and social consciousness which are necessary in order for us to understand how coloniality defeats the self. These psychologies are also attuned to psychosocial well-being and can contribute to the emergence of psychic revolt (Kristeva, 2002) -the rise of being, the constitution and continuous reconstitution of subjectivity, intersubjectivty and voice capable of contesting coloniality.

At Antioch College, in response to student demands for a psychology curriculum for decoloniality, I designed a curriculum stream titled Psychosocial 
Studies/Transformative Psychologies (see Table 1.1 for the sequence of study). This design is based on my understanding of students' desire, my knowledge of transformative psychologies having completed the Depth Psychology doctorate degree program at Pacifica Graduate Institute with an emphasis on community psychology, liberation psychology and ecopsychology, my experience as a participatory researcher, what negotiations with mainstream psychology colleagues and Antioch College's administration yielded, my knowledge of coloniality and decoloniality as a Black woman from the Global South, and my belief that the study of psychology can, and should, support the full realization of our humanity.

I provide below a brief sketch of the rationale for each quarter long course in the Psychosocial Studies/Transformative Psychologies sequence and their respective contributions to the project for decoloniality. Each course had an enrollment cap of 20 students in keeping with the small class size liberal arts institutions in the United States aim for. Small class sizes provide ample opportunity for engaged, dialogic, relational learning (Terenzini and Pascarella, 1998). The sequence that follows reflects a scaffolding approach to teaching where knowledge and understanding are seen to build on prior learning.

Beginning with Foundations of Social Psychology taught from a critical, applied and decolonizing perspective (including indigenous social psychology theory articulated in Social Psychology and Everyday Life by Hodgetts et al. (2010) and research methods) students began studying coloniality and decoloniality through a dialogue between theory, research and by asking questions of each other. They did this as they acted to change the conditions of coloniality on campus through their participation in group ${ }^{6}$ Participatory Action Research projects.

Whitestream psychology's induction course-General Psychology-was replaced by Introduction to Depth Psychology taught from a psychoanalytic social theory perspective. Freud and Beyond (Mitchell \& Black, 1995) provided the theoretical starting point in this course. I designed this course to introduce theories on the dynamics of psychic life, root ideas and concepts that are crucial for people to begin to understand how coloniality becomes internalized within the self. These fundamental ideas helped students understand why social change projects that ignore the effects of unconscious dynamics of oppression sustain coloniality.

Ecopsychology, with its emphasis on relationality between humans and the more than human world, introduced students to beyond Whitestream cosmologies and was a site for engaging theories and praxes known to support, amongst other things, the development of empathy. By witnessing elephants in captivity at the Columbus Zoo, Ohio students came to know the traumatized Other through the emerging field of transspecies psychology (Bradshaw, 2009).

Critical Community Psychology, designed to expose students to foundational theories and praxes from the Global South, provided them with an approach for engaging communities in their social, political and historic contexts in service of social transformation. This course also included some ideas from Critical Psychology. Even

\footnotetext{
${ }^{6}$ Students were required to work in small groups and together engage in a Participatory Action Research project on campus.
} 
though it would have been preferable to offer Critical Psychology as a stand-alone course there were not enough electives available in a liberal arts undergraduate programme to separate this knowledge. Core texts such as International Community Psychology: History and Theories (Reich, Riemer, Prilleltensky, and Montero, 2007), Community Psychology: In Pursuit of Liberation and Well-Being (Nelson and Prilleltensky, 2010) and Revolution in Psychology: From Alienation to Emancipation (Parker, 2007) were readings explored in this course.

Finally, I offered a class titled Liberation Psychology: Some Theory and Praxes as a capstone course in decoloniality. Students in this course were encouraged to produce work that focused on the contestation of coloniality, the dream of decoloniality or work at the intersection of both ways of being through writing projects, developing praxes (preferably in/with community) or creating a piece of liberatory art. Toward Psychologies of Liberation (Watkins and Shulman, 2008) was a central text read in this course.

Table 1.1 Psychosocial Studies/Transformative Psychologies Undergraduate Curriculum ${ }^{7}$

\begin{tabular}{lc}
\hline Sequence of Study & Level/Year \\
\hline Foundations of Social Psychology & 1 \\
Introduction to Depth Psychology & 1 \\
Ecopsychology & 2 \\
Critical Community Psychology & 3 \\
Liberation Psychology: Some Theory and Praxes & 4 \\
\hline
\end{tabular}

Although I was not at Antioch College long enough to have taught this course stream in its entirety I had the opportunity to teach several of these courses. Of the courses I did teach, Liberation Psychology: Some Theory and Praxes most closely met student needs for beginning to dismantle psychic colonization and heal collective trauma. Below is the course description that outlines the material covered in this course.

${ }^{7}$ As an undergraduate institution in the United States higher education system Antioch College offered four year bachelor of arts and bachelor of science degrees. The curriculum outlined here was based on students taking some mainstream psychology and other liberal arts coursework alongside these five courses. 


\section{Liberation Psychology: Some Theory and Praxes Course Description}

Liberation psychology is an emerging body of thought and praxes that has as its central concern what has been excluded and marginalized in psychosocial experience that gives rise to suffering. Through social structures that produce poverty, social injustice, censorship, repression and violence the effects of hegemonic power on the oppressed are explored. As a psychology rooted in desire for well-being this orientation engages in liberatory praxes that seek to transform injury. This course will introduce students to some basic tenets of this interdisciplinary approach drawing from liberation theology, liberation philosophy, Marxist \& feminist theory, (post)colonial thought, critical pedagogy and psychoanalytic social theory. Ideas such as psychic colonization and radical witnessing will be studied for insights they provide. Students will be invited to engage in liberatory praxes including participatory action research and/or liberation arts projects that are instigative of social transformation.

\section{Decolonial Atmospheres and Rising Subjectivities}

One of the conditions of coloniality is social alienation. Students at Antioch College, alert to how remote interpersonal relationships on campus affected their subjectivity and therefore ability to learn began to question how the affectively flat, bleached, inhibiting atmosphere could be transformed. For them, social distance in the classroom felt unhuman and this affected their ability to trust the viability of decolonial theory and to engage in its rehumanizing practices, most notably dialogue. One of our primary tasks in this project therefore was not only to study decoloniality but also to remake our relationships as human beings. We identified a need to create a new environment, one in which subjectivity could come to life restoring intersubjectivity.

Although we did not know it then, students and I were yearning for an "affective atmosphere" (Anderson, 2009, p. 78), an intensity of affect that envelops those present and re/shapes subjectivity. Affective atmospheres are potentially generative because they take advantage of the possibility for subjectivities "to unfold through the relations between bodies and objects that come to constitute a particular atmosphere" (Tucker \& Goodings, 2017, p. 4). In our project the ingredients for the decolonial affective atmosphere we experienced were ourselves, coming together as passionate, intellectual, embodied beings, and bringing our commonly held desire to reclaim our humanity and the decolonial ideas with which we engaged.

During the moments when we experienced a decolonial atmosphere we shifted from engaging with each other discursively and spoke with each other dialogically. That is, we moved away from speech acts described as "a sharing of monologue that often bear no relation to one another except that they address the same topic or question" (Allman, 2001, p. 175) to dialogue in which "members of the group share their thinking [and feeling] about the theme or issue that they are investigating or, alternatively, some "knowledge object" that has been selected in order to help the group members think critically about the theme or issue they are investigating" (p. 175). What specifically 
marks decolonial atmospheres is that this quality of space is where individuals share their knowledge and understanding of social realities and together actively struggle to transform them using their sadness, guilt, shame, anger, desire and love as resources.

Affects become resources when they are experienced as responses to painful histories and when they mobilize political action (Ahmed, 2010). Shared emotion that leads to responsible action is not only an accurate register of pain but also marks the presence of subjective engagement. In the decolonial atmosphere, affect-filled critical self and social reflexivity became social and public acts in service of transforming oppression.

"Freire (1974b) says that dialogue is "the seal" of the transformed relations (p. 21). It is also the vehicle through which the transformations take place." (Allman, 2001, p. 175). If during this rehearsal for decoloniality, some transformation of our being took place, this renewal was made possible by an opportunity to engage our subjectivities which emerged during our learning because we had an intensely affirming environment in which to breathe, think, feel, act and dialogue in.

Below are two liberation art projects developed by students who took Liberation Psychology: Some Theory \& Praxes in the spring of 2016. The course was designed so that students could not only study liberation psychology theories and research but also as a platform for engaging with subjectivities during the learning process. The demand for the course was high and exceeded the class size cap of 20 students. Feedback from students revealed that many experienced a rise in subjectivity, i.e. they became aware of new ways of thinking, experiencing affect and their presence as actors in the world. One psychology major in the cohort struggled to understand their own and other students' subjective experience in the context of coloniality's capitalism. When they contributed to the learning community their understandings of social suffering, healing and well-being relied on theories of abnormal psychology and individual differences.

The two pieces of artwork and accompanying artist's statements are included here as exemplars of increases in subjectivity that can occur when a decolonial atmosphere is created and experienced in the university. They have been chosen to make visible critical, subjective analyses of coloniality based on student's experience of the social world and their use of the theories, praxes and atmosphere available in and through this course. Not all student projects are included in this essay because of space limitations and because their formats (e.g. zines, community dialogues etc.) are not conducive to publication in a journal article. Importantly, the intellectual, affective and relational climate in which the artworks were created existed alongside (or despite) the requirement that students submit assignments for evaluation. Students' work was graded in accordance with the policy at Antioch College which required that both letter and narrative grades be provided. Students were therefore challenged to produce psychosocially meaningful work that met academic criteria outlined in the college's learning outcomes. Many students noted that new subjective experiences, ones that were not available to them prior to taking the course, emerged as a result of their engagement. Anonymized narrative evaluations of the course show the relatedness of subjectivity, intersubjectivity, decolonial theories and praxes and the ensuing decolonial atmosphere:

I feel like a human being (as opposed to a robot trying to merely fulfill requirements and get a good grade)... In this class I have felt like I have a voice and that what I say is important....the curriculum of this class is such that it encourages us to face the most 
important issues in the world and in our communities. I sincerely hope that this class is continued and made a permanent part of Antioch College's curriculum because it has taught me the most about social justice and transformation than any other class at Antioch... it was the first time in my three years at Antioch that I really felt like a valued participant in the classroom. Usually I am very quiet and keep my thoughts to myself, but I felt more comfortable sharing in this space... A survey cannot adequately describe what this class has done for me, and I think my fellow liberation psych mates as well. This class is pure joy, magic, humility, and learning. Learning with a soul, learning in a way that you feel and believe, not regurgitate...This class has shaped and filled up my being with meaning and hope for a community and intimacy and connection. I'm so sad for this class to end, but every aspect of it will be carried through in every part of my life. My faith in learning and in community and myself and in others has been restored. I have never had a finer and more beautiful opportunity than this class... This course should be required for everyone who has a desire to be a social activist. I like that this was all new to me. It gives a very fresh perspective on the field of psychology. This course feels more inclusive and accessible...l enjoyed the emphasis on student engagement toward democratic leadership with regard to class decision-making. Practice dialogues were valuable as were additional readings (done in class and out). Thank you for a lifechanging entrée into this most researchable subject...This class was fantastic and transformative. A quantitative survey is an inefficient way to measure its impact. Courses like this are why I'm a psychology major. Honestly there should be a special major that only looks at humanistic and radical psychologies that Deanne teaches instead of Antioch trying to have a psych program that's like other schools... This course deeply changed how I view the world, my peers and myself. It has given me hope, curiosity, confidence, and a sense of wonder and amazement...A class that addressed all of the liberal arts outcomes and mobilized different ways to think about liberation and forces that cause pain. It was amazing. .. This class will change your life if you let it. It deserves to be its own major, not just a single class... This course was unique and incredible in realizing its objective and moreover creating a par-none learning community...Finally the freedom and encouragement to learn and explore.

Each piece of artwork presented below is followed by the artist's statement, which highlights their knowledge production process (in the case of Stephanie Harman and Ismael Ramirez) and an analytic reflection on the meaning of the image (in the case of Octavio Escamilla-Sanchez). These pieces of work were produced as Final Projects worth $25 \%$ of the total mark possible in this course. The Basis of Evaluation of the entire course is provided to show how scaffolding occurred over the quarter long period of engagement: 
Basis of Evaluation

Students are required to complete all readings and assignments due prior to class.

\section{Active Participation 25\%}

Punctual attendance at every class is required during this course. Full participation in every class is required.

Please bring writing materials to every class as you may be asked to complete a writing assignment during class.

Questionings 40\%

Questioning is a form of revolt necessary to psychic life, especially to sublimation and creativity through which the subject takes social codes or meanings and makes them its own. We become who we are through questioning; and we remain open to meaning and creativity only by continuing to question, continuing this infinite psychic revolt. Psychic revolt is sustained by infinite revolt, or questioning. These small revolts ensure both the individual's autonomy and its assimilation or belonging within the social symbolic order.

$\sim$ Kelly Oliver, The Colonization of Psychic Space, 2004, p. 144

For each part of Toward Psychologies of Liberation (Part I, II, III \& IV) develop a set of questions that are crucial to your psychic life and that mobilize psychic revolt within you. By this, I mean, interrogate the meaning of the world in which you live and the words you read. Your questioning, by necessity, allows you to take an autonomous, independent, critical, unconstrained view of psychosocial experience, as you understand it.

Bring each of the four Questionings to class as per the schedule below. These are formative assignments and will not be graded! You will be given 10\% for each Questioning submitted on time. 5\% for each Questioning submitted within 1 week of the due date. $0 \%$ for a submission after 1 week.

\section{Meditations on Psychic Wounds 10\%}

Please write a 3-4 page in length paper, typed, double-spaced, Times New Roman, 12 point font using APA rules for citing and referencing others' work. This paper should reflect your meditations and musings on what you understand psychic wounds to be. It may be in response to psychic wounds you see in a community you are intimately familiar with or psychic wounds/colonization you understand Nina Simone to experience in the documentary What Happened, Miss Simone. This meditation is due on Monday, June $6^{\text {th }}$. 


\section{Final Project 25\%}

There are many options your final project in this class may take. The following is not an exhaustive list. It is meant to provide you with some ideas for you to engage in research and/or praxes that explore oppression and possibilities for social transformation.

- $\quad$ Engage in participatory action research with an on campus community

- $\quad$ Engage in participatory action research with a community beyond Antioch (this option will require IRB approval which takes time)

- $\quad$ Create a piece of liberatory art

- $\quad$ Create a project linked to the Inside Out class or practicum with Dr. Emily Stienmetz.

- Write a proposal for a piece of community fieldwork that may be central to your senior project

- $\quad$ Propose research or a liberatory arts project that allows you to deeply engage with liberation psychology theory and/or liberatory arts based praxes.

If you choose to write a paper it should be 7-8 pages in length, typed, doublespaced, Times New Roman, 12 point font and use APA rules for citing and referencing others' work.

You may elect to do a group based version of any of the above. If you work collectively on a paper the page length will be 7-8 pages in length times the number of people in your group. E.g. if there are 2 people in a paper project your paper is expected to be 14-16 pages in length. 


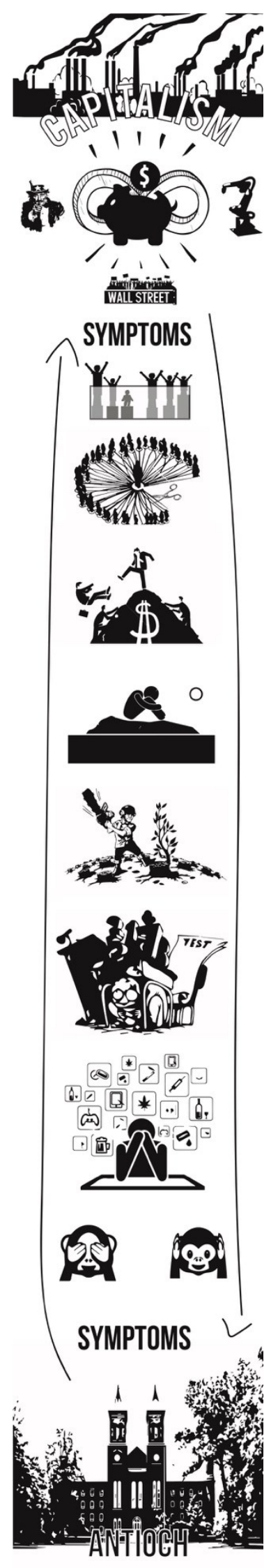


This project had me all over the place. I loved What happened, Miss Simone and was set to have my paper surrounding the psychic wounds seen through the movie and heard through her music. However, working through a project as deep and sometimes painful as this, I didn't want to work on it with just myself. After talking to Ismael Ramirez, a student on campus, an inspiring collaborator, and fellow visionary, we wanted to represent the psychic wounds on campus and how they function under the same system that inflicts psychic wounds here in the states.

This quarter Ismael was in Media, Internet, and Society and we saw it as a golden opportunity to weave in elements of Liberation psychology with his talents in Adobe illustrator.. With Mary Watkins and Helene Shulman in tow, we went to work and hashed out what symbols best represented the psychic wounds on campus and how they are wounds found throughout fiercely individualistic, competitive, industrialized, and, in this context, capitalistic systems.

It was very important for us to use symbols in describing these wounds. This was used in the hopes of appealing to people's own subjectivity and experience. We did not want to directly state something, we wanted people to be able to project what each symbol made them feel and take from the symbols what they need, not what we directly state they need. For each psychic wound we felt on campus, we talked through which symbol resonated with both of us and some of the symbols are made up of multiple symbols that we proposed because we wanted to find a way that both of us felt was representative of our experience.

The concept of this poster was to show two horizons, playing off of concepts of limit situations.

The first visualization of the skylines (moving from top to bottom, although it is not necessary to move in that particular order) were to represent capitalism. We did stream of consciousness, writing or speaking symbols that came to mind when we thought of that word. The piggy bank sign serves as the sun or the central concept, the primary justification and life giver of the capital-based system. It is placed in front of an Infinity sign to show that the pursuit for profit is endless and there is no cap. The representation of profit is surrounded by all of the things it justifies, such as the fracking drill-showing the exploitation of the environment (and also humans) through industry, the Uncle Sam, showing the use of propaganda and mass manipulation of the market, and lastly, a picture of Wall Street, to represent business and free market economy/environmentalism. 
Our next goal was to pick symptoms we have experienced or have seen on campus, and brainstormed to find a representation for each to go on our visualization graphic/poster. The first symbol we chose was the "Preoccupation with personal survival and success preoccupation with personal survival and success."

This section talked about how personalizing your failures removes it from the greater context, which is that the playing field is not even. (Watkins and Shulman, 2008 need page \# for quoted material). It is built into our system the people of color and people of low-income do not have the same access to resources and opportunities as white folks in this country. It talks about the misattribution of failure and the disparities worked into the system. We chose the first symbol symptom to represent equality versus equity, to show that we knew of this symbol all, too well, unfortunately. This was easiest imagined, for me, in the context of severing of the self. This looked like a person separating the parts of themselves deemed inferior, or unable to meet the unnatural standards of society, or an edubusiness such as this one. We both talked about our difficulties meeting deadlines and writing papers while still keeping the "weak" parts of ourselves, aka the parts of ourselves that are unable to meet the standards. Often, we blame ourselves as individuals and due to our severed selves, don't want to reach out to others for the fear of revealing our weakness. We talked about how sometimes it feels the only option provided on campus to aid these "weaknesses" and the resulting anxiety from it is with medication or other substances. This process brought us to the image of the person cowering under the desk with things to do and tests some people start with more privilege, but are given the same stepping stool (so to speak) as someone starting off with significantly less privilege.

The second symptom we chose was "The severing of the self". This talks about how people are often educated in an individualistic and competitive pedagogy of schooling. This starts the separation of self from other. Under this system, it is every person for themself and if someone needs to lean on another for support, it is pathologized (Watkins and Shulman, 2008).

This brought us to the next symptom which is "comparative neurosis." This is when we started realizing how intertwined all of these symptoms are and the way they feed off of each other. In an extremely competitive setting, the goal can become separating yourself from others yet again, this time in a more vertical fashion (Watkins and Shulman, 2008). This comes with the notion of superiority and inferiority as well, further splitting people apart. In addition to this, the writers speak about needing to push others away and down to get ahead. (Watkins and Shulman, 2008). We represented this symptom with people pushing each other off a mountain for the sack of capital gain, a way of gaining control. 
Loneliness seems to be a symptom of Bystanding, our current symptoms, but also a symptom of the other symptoms. The constant separation and distinction from others and constantly needing to push others down to survive, and parts of yourself to be productive results in isolation and loneliness. Something that is easy to come by on this campus. We thought this symbol of someone curled on a bed represented our head spaces when lonely. It's hard to look up and see people for people, it's easy to think you're the only one going through it.

"Degrading of others"

This one was the one we had a hard time visualizing a symbol for. After reading the passage we decided it was best to show it in the form of deforestation. We understood this as removing one's subjectivity or existence, human or non-human. Through the process of objectification, you remove someone's context or life, it becomes devalued. Helene Shulman and Mary Watkins said that objectification allows us to justify atrocity through the pursuit of profit (Watkins and Shulman, 2008). Which can be seen often in the removal of forests for the capital it brings.

"Fear of oneself, the abject"

This part played a lot into "The empty self" for me. If we aren't meeting standards and being punished for it, are constantly competing and comparing ourselves to others, degrading others or putting them in an inferior category, it is easy to feel empty. It's easy to feel empty without connection to people and our environment. The substance abuse on campus that we talked about is in many ways heart wrenching. The worst part about it, is often times both of us found ourselves engaging in behaviors to fill us with something, a feeling, a connection, an escape, whatever it may be. There is so much pressure and competition and deadlines and worries on worries involved in this place with very little outlet. This was portrayed as a person sitting at a desk to absorb and regurgitate information with substances and passive stimulation surrounding them.

"Psychic numbing"

This came to us in the form of see no evil and hear no evil. It was, to us, the ultimate denial and turning away from issues, pains, and atrocities. Which is also very present on our campus. We talked about the differences in acknowledging something and truly seeing that something. This was the source of not changing things, the excuse to further the barriers between us, and ultimately keeps people apart. It also allows the meanings of symptoms to go unchecked.

All in all, the visualization ends with the horizon/skyline of Antioch. To show that just because we acknowledge a radical vision, does not mean it exists here. We still suffer and function under the means to an end with profit as a goal. It is still a business, a market, an objectification, in many ways. Many don't acknowledge the substance abuse on campus, the high rates of prescription medications as solutions, the competitive air in the classes, the separation students feel vertically with the administration and horizontally with each other. We have a lot of steps left to take, but we hoped this art project would bring us to the realm of disrupting thought or adding imagination to psychic space, or hopefully ignite a fire to make change. We certainly felt that this was a cathartic step for us.

Stephanie Harman 


\section{Illegals}

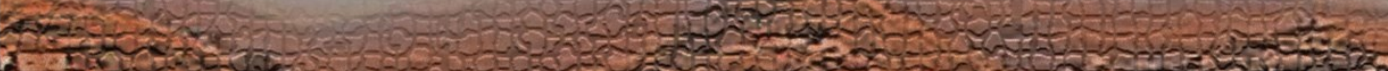
K.

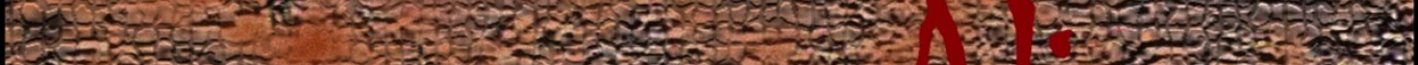

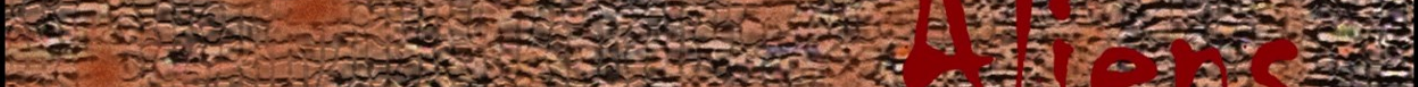

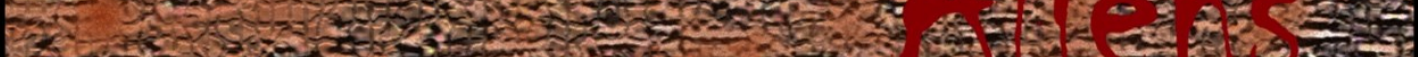

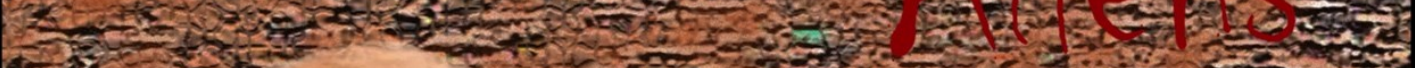

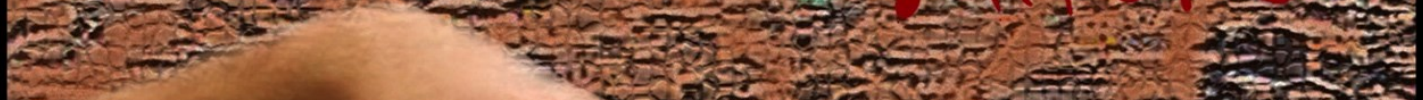

$\operatorname{sen}^{2}$

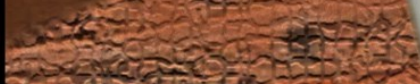

Toustives

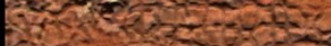

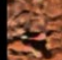

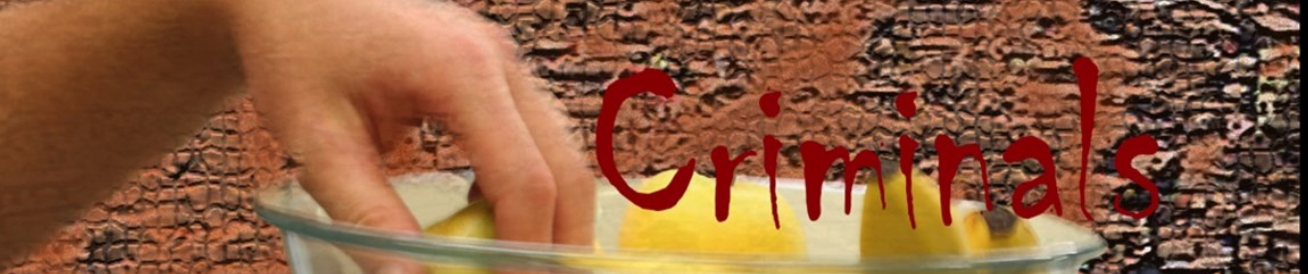

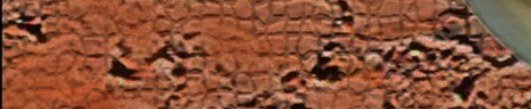

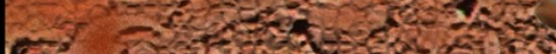

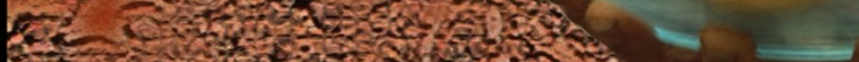

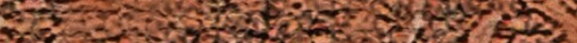

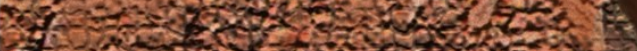

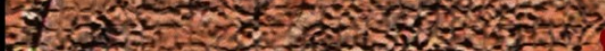

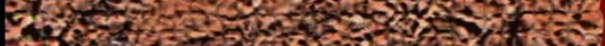

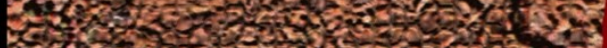

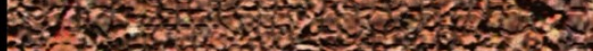

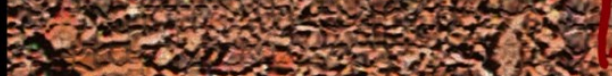

3. o. 2.

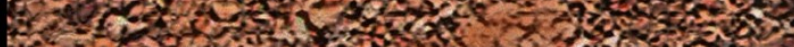

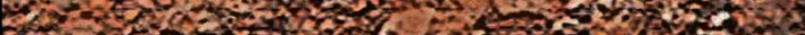

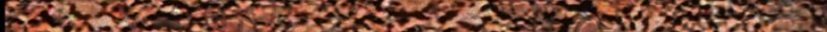

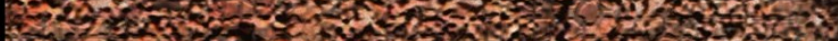
a.

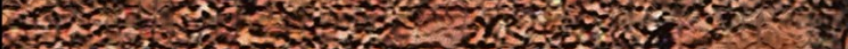

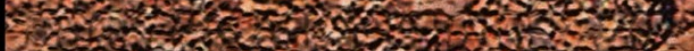

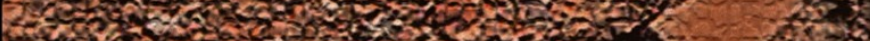

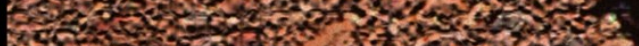

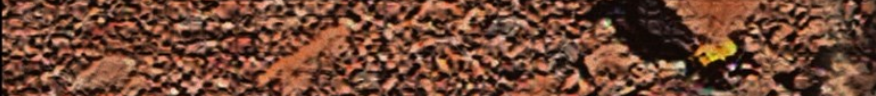


The work stages my complete disagreement with the fascist rhetoric Donald Trump has catalyzed in a dormant hatred towards immigrants, particularly Latinx immigrants. What he and his supporters fail to understand is that economic interplay between the U.S. and Latin America created free trade, but not free labor movement. This has pushed immigrants to the U.S. for financial stability. This work, with painful blood dripping text, provides the remarks Trump vocalises. I say painful because as the image demonstrates an example, the majority of this population are exploited for the fruit of their labour; instead of their appreciation, they are marginalised and portrayed grotesquely.

Octavio Escamilla-Sanchez (work was created in the Spring of 2016 with the artist statement written December 10,

8

Concluding Thoughts

The student projects included above are not submitted as data since this publication is not a research article. I included student's work in this essay because doing so aligns with a core community psychology principle of not speaking for others since all subjects have a voice. The projects included here make visible student's critical, subjective analyses of coloniality, on their own terms. Their inclusion is seen as part of a plurality of voice we should strive for in academic publications concerned with decolonial subjectivity.

The work this essay seeks to do is to illuminate dimensions of decolonial praxes that are not adequately explored in the literature. The concept of rehumanization appears in writings on coloniality and decoloniality however the conditions under which we experience full humanness is undertheorized. Fanon (1967) took us to the edge of this imperative when he referred to the need for love yet how love manifests in community is rarely articulated in academic journals.

This essay articulates aspects of a decolonial atmosphere co-created with students in an academic institution founded on social justice values. It attempts to identify the conditions that supported the emergence of a climate in which analytic, affective and intersubjective experiences facilitated shifts in consciousness leading to rising subjectivity. I designed and taught the curriculum stream that supported the development of student voice as the sole community and liberation psychology faculty member at Antioch College at that time. What made this rehearsal in decoloniality within the university possible was student demand and a commitment on the part of the Antioch College administration to support creative, engaged learning. Since leaving Antioch College some students have expressed regret that this coursework stream is no longer available to them.

\footnotetext{
${ }^{8}$ Octavio Escamilla-Sanchez' artist statement was a reflection produced approximately nine months after the end of the Liberation Psychology: Some Theory \& Praxes course. This ongoing engagement with ideas produced in the course may speak to the effects of an education that is psychosocially relevant to students' lives.
} 
This project, and similar projects taking place elsewhere, can be understood as facilitative of the emergence of a decolonial attitude (Maldonado-Torres, 2017) within the Whitestream world. Decolonial atmospheres promote decolonial attitudes which form the basis for creating rehumanizing praxes for healing from collective trauma. Healing from oppression's pain, with one another, could return us to a state where the self is prized and can rise in and through community. This was a vision I shared with students who demanded a new psychology curriculum and learning experience. The expansion of this dream would see people invited into a form of psychological engagement (theoretically and in embodied ways) that recasts psychology as a productive and liberatory force.

I believe it is possible for this vision of the world to be realized. Although coloniality appears intractable, it is, as Memmi observed "impossible for the colonial situation to last because it is impossible to arrange it properly" (1965, p. 146). An effective tool capable of disrupting its continuity is a group of psychologies which, when taught together, promote decoloniality. But decoloniality exceeds theory. It requires engagement as emotional, embodied beings whose transformation becomes possible as self-knowledge and understanding increases. It can be realized in an atmosphere where people (with access to the full range of their humanity including their affect) take up decolonial theories and praxes in ways that reshape subjectivity. It is, fundamentally, a project driven by our desire for rehumanization.

\section{Acknowledgements}

I am grateful to the people at Antioch College who, as students, demanded a curriculum to better understand and repair the world in which they live. I am particularly grateful to Stephanie Harman, Ismael Ramirez and Octavio Escamilla-Sanchez for giving me permission to include their art work in this essay. 


\section{References}

Ahmed, S. (2010). The cultural politics of emotion. New York: Routledge.

Allman, P. (2001). Critical education against global capitalism: Karl Marx and revolutionary critical education. South Hadley, MA: Bergin \& Garvey.

Anderson, B. (2009). Affective atmospheres. Emotion, space and society. 2(2). 77-81. https://doi.org/10.1016/j.emospa.2009.08.005

Antioch College (2017). Mission and history. Retrieved from Antioch College website: http://www.antiochcollege.edu/about/mission_and history.html

Bradshaw, G.A. (2009). Elephants on edge: What animals teach us about humanity. London: Yale University.

Fanon, F. (1967). Black skins, white masks. In R. Philcox (Trans.). New York: Grove.

Grande, S. (2008). Red pedagogy: The un-methodology. In Denzin, N.K., Lincoln, Y.S. \& Tuhiwai Smith, L. (Ed.), Handbook of critical and indigenous methodologies. DOI: http://dx.doi.org/10.4135/9781483385686.n12

Hodgetts, D., Drew, N., Sonn, C., Stolte, O., Nikora, L.W., \& Curtis, C. (2010). Social psychology and everyday life. New York: Palgrave Macmillan.

Kleinman, A., Das, V., \& Lock, M. (2003). Introduction. In A. Kleinman, V. Das \& M. Lock. Los Angeles: University of California Press.

Kristeva, J. (2002). Revolt, she said. Los Angeles: Semiotext(e).

Landerman, L.M. \& MacDonald-Dennis, C. (2013). The evolution of social justice education and facilitation. In L M. Landreman (Ed.), The art of effective facilitation: Reflections from social justice educators. http://0web.b.ebscohost.com.lib.exeter.ac.uk/ehost/ebookviewer/ebook/bmxlYmtfXzY2 MjU5MV9fQU41?sid=b59f2cdd-2793-48c8-9263942739672a58@sessionmgr104\&vid=0\&format=EK\&lpid=ich00 fm05 contents $\underline{\& \text { rid }=0}$

Nelson, G. \& Prilleltensky, I. (ed) (2010). Community psychology: In pursuit of liberation and well-being. New York: Palgrave Macmillan.

Maldonado-Torres, N. (2017). Frantz Fanon and the decolonial turn in psychology: From modern/colonial methods to the decolonial attitude. South African Journal of Psychology. Vol. 47(4) 432-441. 
Maldonado-Torres, N. (2016). "Outline of Ten Theses on Coloniality and Decoloniality", Foundation Frantz Fanon. Retrieved from http://frantzfanonfoundationfondationfrantzfanon.com/IMG/pdf/maldonado-torres_outline_of_ten_theses10.23.16_.pdf

Memmi, A. (1965). The colonizer and the colonized. Boston, MA: Beacon.

Mitchell, S.A., \& Black, M. J. (1995). Freud and beyond: A history of modern psychoanalytic thought. New York: Basic.

Oliver, K. (2004). The colonization of psychic space. Minneapolis, MN: University of Minnesota.

Parker, I. (2007). Revolution in psychology: Alienation to emancipation. London, Pluto.

Reich, S. M., Riemer, M., Prilleltensky, I., \& Montero, M. (ed) (2007). International community psychology: History and theories. New York: Springer.

Santos, Boaventura de Sousa (2012), "The University at a Crossroads", Human Architecture: Journal of the Sociology of Self-Knowledge, X, Issue 1, Winter 2012, 7-16.

Teo, T. (2010). What is epistemological violence in the empirical social sciences? Social and personality psychology compass. 4(5). 295-303.

Terenzini, P.T, \& Pascarella, E.T. (1998). Studying Colleges in the $21^{\text {st }}$ Century: Meeting New Challenges. The Review of Higher Education 21(2), 155-165. Johns Hopkins University Press. Retrieved October 24, 2018, from Project MUSE database.

Tucker, I.M. \& Goodings, L. Digital atmospheres: Affective practices of care in Elefriends. Sociology of health \& illness. 39(4) (DOI: 10.1111/1467-9566.12545 